\title{
MODULATION OF CULTURE MEDIUM ON THE EX SITU CONSERVATION OF Neoregelia mucugensis Leme (BROMELIACEAE) ${ }^{1}$
}

\author{
ANDRESSA PRISCILA PIANCÓ SANTOS LIMA ${ }^{2 *}$, FERNANDA DE JESUS OLIVEIRA BASTOS ${ }^{2}$, ALONE LIMA- \\ BRITO $^{2}$, GILÊNIO BORGES FERNANDES ${ }^{3}$, JOSÉ RANIERE FERREIRA DE SANTANA ${ }^{2}$
}

\begin{abstract}
Bromeliads are the target of predatory extractivism and consequently many species are included in the red list of threatened species, such as those belonging to the genus Neoregelia. Although Neoregelia mucugensis has not been evaluated for the degree of threat, its exploitation is exclusively extractive and its occurrence in Chapada Diamantina-BA is subject to the action of fires that affect the region annually. In this context, applying techniques aimed at protecting this genetic resource is fundamental for both the maintenance of its natural populations and the ex situ conservation of this genetic material. Plant tissue culture techniques have been successfully applied for the conservation of several bromeliad species. One of the methods used is slow growth, which consists in reducing plant metabolism and consequently decelerating its growth, which allows the maintenance of in vitro plant collections without the need for subculture. In this context, the objective of this study was to test the reduction of salts in the culture medium and the addition of osmoregulators on the induction of slow growth of $N$. mucugensis. Plants were subjected to treatments composed of different concentrations of MS medium and mannitol for a period of 12 months, when then analyses were conducted to evaluate growth, chlorophyll content and regeneration capacity of shoots in vitro. It was found that the treatment containing MS $1 / 2$ and 7.8 g.L $\mathrm{L}^{-1}$ of mannitol is indicated for in vitro conservation of N. mucugensis with maintenance of the regenerative capacity of its tissues.
\end{abstract}

Keywords: Slow growth. Bromeliad. Osmoregulators.

\section{MODULAÇÃO DO MEIO DE CULTURA NA CONSERVAÇÃO EX SITU DE Neoregelia mucugensis Leme (BROMELIACEAE)}

\begin{abstract}
RESUMO - As bromélias são alvo de extrativismo predatório e com isso muitas estão inseridas na lista vermelha de espécies ameaçadas, a exemplo das que pertencem ao gênero Neoregelia. Apesar da Neoregelia mucugensis não ter sido avaliada quanto ao grau de ameaça, sua exploração é exclusivamente extrativista e sua ocorrência na Chapada Diamantina-BA está sujeita à ação das queimadas que afetam a região anualmente. Neste contexto, a aplicação de técnicas que visem proteger este recurso genético é fundamental tanto para manutenção de suas populações naturais quanto para conservação ex situ deste material genético. Técnicas de cultura de tecidos vegetais têm sido aplicadas com êxito para conservação de diversas espécies de bromélias. Um dos métodos utilizados é o crescimento lento que consiste na redução do metabolismo da planta e consequentemente na desaceleração do seu crescimento, o que possibilita a manutenção das coleções de plantas in vitro sem necessidade de subcultivo. Neste sentido, o objetivo deste trabalho foi testar a redução de sais do meio de cultura e a adição de osmorregulador na indução do crescimento lento de $N$. mucugensis. Plantas foram submetidas a tratamentos compostos por diferentes concentrações do meio MS e de manitol pelo período de 12 meses, quando então foram realizadas as análises de crescimento, teor de clorofila e capacidade de regeneração de brotos in vitro. Constatou-se que o tratamento contendo MS $1 / 2$ e 7,8 g. $\mathrm{L}^{-1}$ de manitol é indicado para a conservação in vitro de $N$. mucugensis com manutenção da capacidade regenerativa dos seus tecidos.
\end{abstract}

Palavras-chave: Crescimento lento. Bromélia. Osmorregulador.

\footnotetext{
*Corresponding author

${ }^{1}$ Received for publication in $10 / 28 / 2020$; accepted in 05/31/2021.

Paper extracted from the doctoral thesis of the first author.

${ }^{2}$ Department of Biological Sciences, Universidade Estadual de Feira de Santana, BA, Brazil; andressapianco@gmail.com - ORCID: 0000-0002-8272-3506, fernandabastos.uefs@gmail.com - ORCID: 0000-0001-7180-6405, alone@uefs.br - ORCID: 0000-0003-3481-6481, jose.raniere@gmail.com - ORCID: 0000-0003-0186-6888.

${ }^{3}$ Department of Exacts, Universidade Estadual de Feira de Santana, BA, Brazil; gbfernandes@uefs.br ORCID: 0000-0002-2364-0954.
} 


\section{INTRODUCTION}

Bromeliads are floristic representatives of marked ecological importance. Since the arrangement of its leaves forms 'tanks' that accumulate nutrient-rich water (JENSEN et al., 2011), producing ecological niches, which house fauna and flora (SCHUTTZ; ARAÚJO; SÁ, 2012). In addition, they have high market acceptance due to exuberance and post-harvest durability (SILVA et al., 2014). The variety of colors and shapes gives them significant ornamental potential and consequent economic importance, making these plants a target of predation (PALHA et al., 2018), which impacts population distribution and creates risk of extinction.

Neoregelia mucugensis Leme is a rupicolous Bromeliad, endemic to Brazil, occurring in the phytogeographic domain of the Caatinga (FLORA DO BRASIL, 2020), with distribution in Chapada Diamantina, BA, Brazil. Although several species of this genus are on the Red List of threatened species (CNCFLORA, 2012), N. mucugensis has not yet been evaluated. Its exclusively extractive exploitation and occurrence in areas subject to fires require strategies to minimize the risk of genetic erosion. In this context, biotechnology provides successful tools such as plant tissue culture that can be used for the micropropagation and ex situ conservation of this genetic resource.

The potential application of tissue culture for ex situ conservation of species of the Bromeliaceae family has been reported for Aechmea bambusoides L. B. Sm. \& Reitz (FIGUEIREDO et al., 2008), Neoglaziovia variegata (Arruda) Mez (SILVEIRA et al., 2009), and Vriese flammea L.B.Sm. (SASAMORI; ENDRES-JUNIOR; DROSTE, 2020), using the in vitro conservation technique.

It can be performed by the slow growth method, which aims to increase the subculture intervals, promoting reduction of costs with reagents and labor (BELLO-BELLO; GARCÍA-GARCÍA; IGLESIAS-ANDREU, 2015). This method consists in reducing plant metabolism, commonly obtained by modifications in the chemical composition of the culture medium (SÁ; LÊDO; LÊDO, 2011), related to the removal, reduction and/or addition of substances.

Addition of osmoregulators such as mannitol is among the most used strategies to reduce the potential in the medium and consequently limit plant growth (SILVA et al., 2016). Mannitol is characterized as hexahydric alcohol, and causes differences in water potentials when in solution (CARVALHO et al., 2016), being a non-toxic inert compound for plants (FERREIRA et al., 2017). In addition to mannitol, sucrose as it is the most commonly used carbohydrate in in vitro culture (BETTENCOURT et al., 2016) can be used both as an energy source and as an osmotic agent.
Another method that can be applied for in vitro plant conservation, alone or associated with osmotic agents, is the reduction of salt concentrations in the culture medium, which directly reduces the supply of nutrients to plants.

The establishment of in vitro plant collections should be carried out from seeds (SILVEIRA et al., 2009), as it ensures variability and contributes to the non-removal of individuals from nature. In addition, periodic evaluation of the regenerative capacity of preserved plant material is essential to ensure that it is used in the production of new plants.

Considering that studies with $N$. mucugensis are limited to in vitro germination and regeneration (BELLINTANI et al., 2007, 2008) and based on the hypothesis that tissue culture is an alternative for $e x$ situ conservation, the aim of this study was to evaluate the reduction of salts and addition of osmoregulators to the medium on the induction of slow growth.

\section{MATERIAL AND METHODS}

\section{Plant material and germination}

Neoregelia mucugensis seeds were collected in Mucugê Municipal Park - Mucugê, Chapada Diamantina, Bahia, Brazil (12 ${ }^{\circ} 59^{\prime} 47^{\prime \prime}$ South, $41^{\circ} 22^{\prime}$ 11" West). These were disinfested and later inoculated in culture medium MS (MURASHIGE; SKOOG, 1962) with half salt concentrations plus 30 g. $\mathrm{L}^{-1}$ of sucrose and $7 \mathrm{~g} . \mathrm{L}^{-1}$ of agar for germination according to Bellintani et al. (2007). Plants germinated in vitro with approximately $3 \mathrm{~cm}$ were used in the experiments.

\section{In vitro conservation}

The plants were inoculated in test tubes $(25 \mathrm{x}$ $150 \mathrm{~mm}$ ) containing $18 \mathrm{~mL}$ of MS culture medium with half $(1 / 2)$ and one third (1/3) salt concentrations, plus 7 g. $\mathrm{L}^{-1}$ of agar, 45 g. $\mathrm{L}^{-1}$ of sucrose and mannitol in the concentrations of 7.8 and 15.6 g. $\mathrm{L}^{-1}$, forming four treatments: T1 - MS $1 / 2+45$ g. $\mathrm{L}^{-1}$ sucrose + 7.8 g. $\mathrm{L}^{-1}$ mannitol; T2 - MS $1 / 3+45$ g.L $\mathrm{L}^{-1}$ sucrose + 7.8 g. $\mathrm{L}^{-1}$ mannitol; T3 - MS $1 / 2+45$ g.L $\mathrm{L}^{-1}$ sucrose + 15.6 g.L L $^{-1}$ mannitol; T4 - MS $1 / 3+45$ g. $\mathrm{L}^{-1}$ sucrose + 15.6 g. $\mathrm{L}^{-1}$ mannitol. The $\mathrm{pH}$ of the culture medium was adjusted to 5.8 and sterilization was performed in autoclave at $120^{\circ} \mathrm{C}$ for 15 minutes.

The experimental design was completely randomized (CRD) with 50 tubes per treatment, each treatment composed of ten replicates and five samples per replicate (one plant per tube).

After 12 months of conservation, the percentage of survival $(\% \mathrm{~S})$ of the plants was recorded, and growth analyses (15 samples of each treatment) were conducted to evaluate: number of green leaves (NGL), number of senescent leaves 
(NSL), shoot length (SL) and longest root length (LRL), number of roots (NR), shoot fresh mass (SFM), root fresh mass (RFM), shoot dry mass (SDM) and root dry mass (RDM). To obtain the dry mass, the samples of the plants were kept in a forced circulation oven at $65^{\circ} \mathrm{C}$ until obtaining a constant weight. Chlorophyll content and regenerative capacity were also analyzed using 15 samples of each treatment.

\section{Chlorophyll content}

Chlorophyll content was determined according to the methodology of Arnon (1949) with adjustments. For this, healthy green leaves were detached from plants conserved in vitro and $0.5 \mathrm{~g}$ was weighed for each sample. Subsequently, these leaves were macerated with $15 \mathrm{~mL}$ of $80 \%$ acetone and then filtered on filter paper. The filtered part was completed with $80 \%$ acetone to $25 \mathrm{~mL}$ and then the absorbance was measured in spectrophotometer at wavelengths of 645 and $663 \mathrm{~nm}$. The analyses were performed in triplicate for each treatment.

In the calculation of chlorophyll, the following formulas were used:

Chlorophyll a $\left(\mu \mathrm{g} . \mathrm{mL}^{-1}\right)=12.7 \mathrm{~A}_{663}-2.69 \mathrm{~A}_{645}$

Chlorophyll b $\left(\mu \mathrm{g} . \mathrm{mL}^{-1}\right)=22.9 \mathrm{~A}_{645}-4.68 \mathrm{~A}_{663}$

Total chlorophyll $\left(\mu \mathrm{g} . \mathrm{mL}^{-1}\right)=20.2 \mathrm{~A}_{645}+8.02 \mathrm{~A}_{663}$

\section{Regenerative capacity}

To analyze the shoot formation capacity of plants conserved in vitro for 12 months, $0.5 \mathrm{~cm}$ long stem explants were inserted into test tubes containing $15 \mathrm{~mL}$ of MS culture medium with half of the salt concentrations, 15 g. $\mathrm{L}^{-1}$ of sucrose, 7 g.L $\mathrm{L}^{-1}$ of agar, plus $2.22 \mu \mathrm{M}$ of BAP combined with $1.30 \mu \mathrm{M}$ of ANA (BELLINTANI et al., 2008).

The CRD consisted of four treatments (of conservation), each composed of 15 replicates, with one sample each.

After 60 days, the percentage of explants responsive to shoot formation (\%RE) via direct organogenesis and the number of shoots per explant (NS) were evaluated.

\section{Culture conditions}

The cultures were kept in the growth room at a temperature of $25 \pm 3{ }^{\circ} \mathrm{C}$, photoperiod of $16 \mathrm{~h}$ and active photosynthetic radiation of $60 \mu \mathrm{mol} \cdot \mathrm{m}^{-2} \cdot \mathrm{s}^{-1}$.

\section{Statistical Analysis}

Prior to performing the classical analysis of variance (ANOVA), the tests of normality and homogeneity of variance were applied in the treatments. For variables that did not reject the hypothesis of normality and homogeneity of variance, ANOVA was applied and for the variables that did not meet the assumptions of normality and homogeneity of variances, the analyses were performed based on the theory of generalized linear models. Whenever the hypothesis of equal treatment means was rejected, multiple means comparison tests were performed. All hypotheses were tested at 5\% significance level, and the analyses were processed using the statistical program R (R CORE TEAM, 2018).

\section{RESULTS AND DISCUSSION}

N. mucugensis plants conserved in vitro show the efficiency of treatments applied to induce their slow growth (Figure 1) because they had high survival rates, 92 to $96 \%$, after the period of 365 days of in vitro culture. The analysis of variance indicated a non-significant effect $(p \geq 0.05)$ of the treatments on the percentage of survival of the conserved plants (Figure 2).

This high survival of plants under conditions of high osmotic potential demonstrates the resistance of $N$. mucugensis to the stress situation, which may be related to its natural habitat. Since this species occurs in litholic, quartzic and acidic soils, whose vegetation is composed of plants resistant to water stress or with tolerance to desiccation (RAPINI et al., 2008).

Similar results were obtained in studies on in vitro conservation of ornamental plants, which tested the use of mannitol and recorded a survival rate of 90\% for Comanthera mucugensis (Giul.) L.R. Parra \& Giul. (Erirocaulaceae) (LIMA-BRITO et al., 2011) and for Vanilla planifolia Jacks. ex Andrews (Orquidaceae) (BELLO-BELLO; GARCÍAGARCÍA; IGLESIAS-ANDREU, 2015) for a period of 180 days.

The statistical analysis for counting variables indicated a significant effect $(p \leq 0.05)$ of the treatments on the number of senescent leaves (NSL) and number of roots (NR), and not significant $(p \geq 0.05)$ on the number of green leaves (NGL) (Figure 3). 


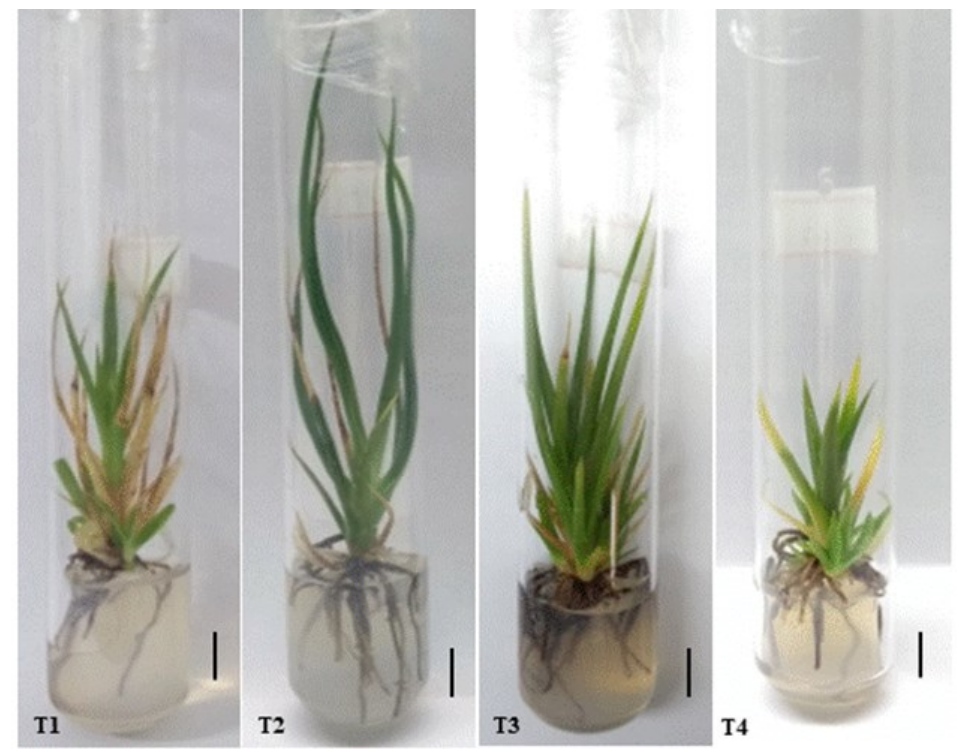

Figure 1. Neoregelia mucugensis plants stored in vitro for 365 days. T1 - MS $1 / 2+45$ g. $\mathrm{L}^{-1}$ sucrose +7.8 g.L $\mathrm{L}^{-1}$ mannitol; T2

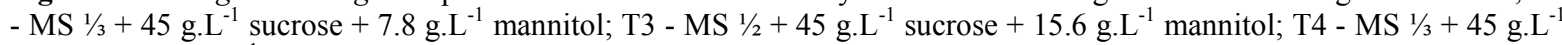
sucrose +15.6 g.L $\mathrm{L}^{-1}$ mannitol. Bar: $1 \mathrm{~cm}$.

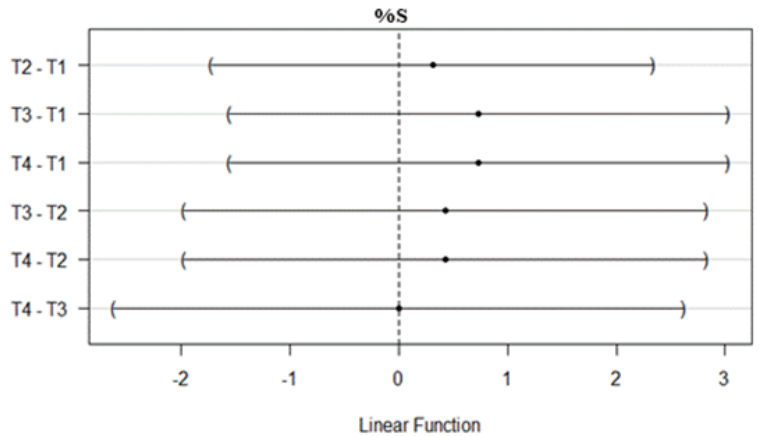

Figure 2. Statistical difference for percentage of survival $(\% \mathrm{~S})$ between treatments with in vitro conservation of Neoregelia mucugensis. T1 - MS 1/2 + 45 g. $\mathrm{L}^{-1}$ sucrose +7.8 g.L $\mathrm{L}^{-1}$ mannitol; T2 - MS $1 / 3+45$ g.L $\mathrm{L}^{-1}$ sucrose +7.8 g.L $\mathrm{L}^{-1}$ mannitol; T3 MS $1 / 2+45$ g.L $L^{-1}$ sucrose +15.6 g. $L^{-1}$ mannitol; T4 - MS $1 / 3+45$ g. $L^{-1}$ sucrose +15.6 g.L $\mathrm{L}^{-1}$ mannitol, after 365 days of culture.
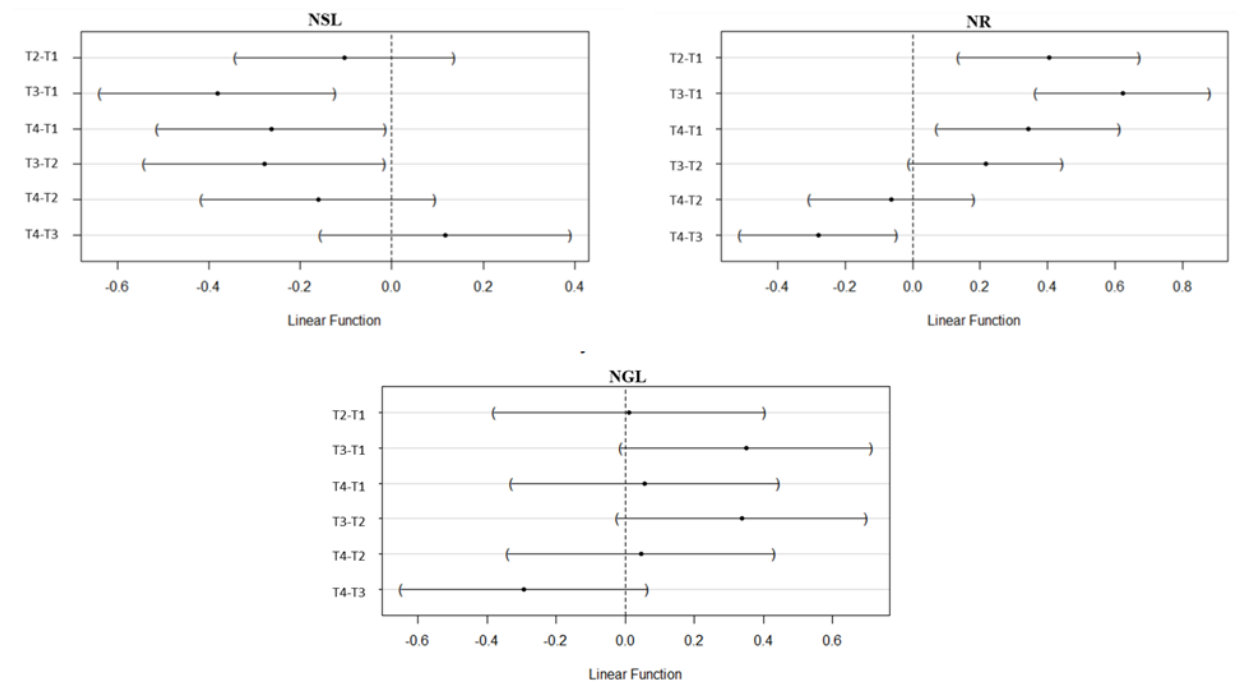

Figure 3. Statistical difference for the numbers of senescent leaves (NSL), roots (NR) and green leaves (NGL), between treatments with in vitro conservation of Neoregelia mucugensis. T1 - MS $1 / 2+45$ g. $\mathrm{L}^{-1}$ sucrose +7.8 g.L $\mathrm{L}^{-1}$ mannitol; T2 MS $1 / 3+45$ g.L $L^{-1}$ sucrose +7.8 g.L $L^{-1}$ mannitol; T3 - MS $1 / 2+45$ g.L ${ }^{-1}$ sucrose +15.6 g.L . $^{-1}$ mannitol; T4 - MS $1 / 3+45$ g.L $L^{-1}$ sucrose +15.6 g.L $\mathrm{L}^{-1}$ mannitol, after 365 days of culture.

Rev. Caatinga, Mossoró, v. 34, n. 4, p. 763 - 771, out. - dez., 2021 
The treatments tested showed means from 5.73 to 8.13 for NGL per plant. Regarding NSL, treatments 3 and 4, which contained the highest concentration of mannitol, had significantly lower means compared to treatments 1 and 2 (Table 1). Mannitol acts in the culture medium as an osmotic agent since it is a polyol usually slowly absorbed by plants, which increases the solute potential of the medium, generating a more negative water potential, which reduces the availability of free water and consequently causes a lower absorption of nutrients and carbohydrate by the plant. This leads to a slow development of plants that is evidenced by the lower means of NSL, as senescence is a process of aging, which will be faster as the development becomes more accelerated under stress conditions, since senescence redistributes nutrients to growing regions of the plant (TAIZ et al., 2017).
In addition, the senescence process can be accelerated by in vitro stress due to the limitation of gas exchange and/or insufficiency of nutrients (RODRIGUES; ARRUDA; FORTI, 2018). Both factors may have occurred for $N$. mucugensis since the sealing of the tubes with PVC prevents the exchanges between the internal environment of the tube and the growth room, and the more negative osmotic potential generated by the addition of $15.6 \mathrm{~g} . \mathrm{L}^{-1}$ of mannitol interferes in the absorption of nutrients and water by plants.

For NR, the lowest mean was generated by T1, differing statistically from the others (Table 1). A high number of roots is not interesting for the in vitro conservation of the species under study, as there was a faster consumption of the culture medium with a consequent need for subculture, which causes an increase in costs with reagents and labor.

Table 1. Numbers of senescent leaves (NSL) and roots (NR), as a function of treatments with in vitro conservation of Neoregelia mucugensis after 365 days of culture.

\begin{tabular}{ccccc}
\hline Treatment & Salt concentration (MS) & Mannitol (g.L $\left.{ }^{-1}\right)$ & NSL & NR \\
\hline T1 & $1 / 2$ & 7.8 & $16.4 \mathrm{~A}$ & $10.26 \mathrm{C}$ \\
T2 & $1 / 3$ & 7.8 & $14.8 \mathrm{~A}$ & $15.4 \mathrm{AB}$ \\
$\mathrm{T} 3$ & $1 / 2$ & 15.6 & $11.2 \mathrm{~B}$ & $19.13 \mathrm{~A}$ \\
$\mathrm{~T} 4$ & $1 / 3$ & 15.6 & $12.6 \mathrm{~B}$ & $14.46 \mathrm{~B}$ \\
\hline
\end{tabular}

Means followed by the same uppercase letters in the columns do not differ from each other by Tukey test at $5 \%$ probability level.

For continuous variables, there were significant effects $(\mathrm{p} \leq 0.05)$ on SL, SFM and SDM, and not significant effects $(\mathrm{p} \geq 0.05)$ on LRL, RFM and RDM (Figure 4).

SL had higher mean in $\mathrm{T} 2$, differing statistically from the other treatments (Table 2), however, for in vitro conservation it is ideal that the plants have a slow growth, so the treatments that recorded the lowest means (T1, T3 and T4) were those of real interest. Treatment 2 , composed of the lowest concentrations of MS (1/3) and mannitol (7.8 g. $\left.\mathrm{L}^{-1}\right)$, probably had a less negative water potential, making more free water available to the culture medium and, consequently, promoting a greater absorption of macro and micronutrients and sucrose by plants.
For $C$. mucugensis, the presence of mannitol led to the lowest means for SL in the study conducted by Lima-Brito et al. (2011) when compared to the presence of other carbohydrates such as sorbitol and sucrose.

In relation to shoot fresh mass and dry mass, treatments 2 and 3 had means with no statistical difference between them and significantly higher than the means of the others (Table 2) osmotic potential of the culture medium.

Regarding chlorophyll content, the results presented here show that in all treatments chlorophyll $a$ and $b$ fractions are equated. The plants conserved in vitro for a period of one year differed between all the treatments, and treatment 3 had the lowest means for both total chlorophyll and chlorophylls $a$ and $b$ (Figure 5). 

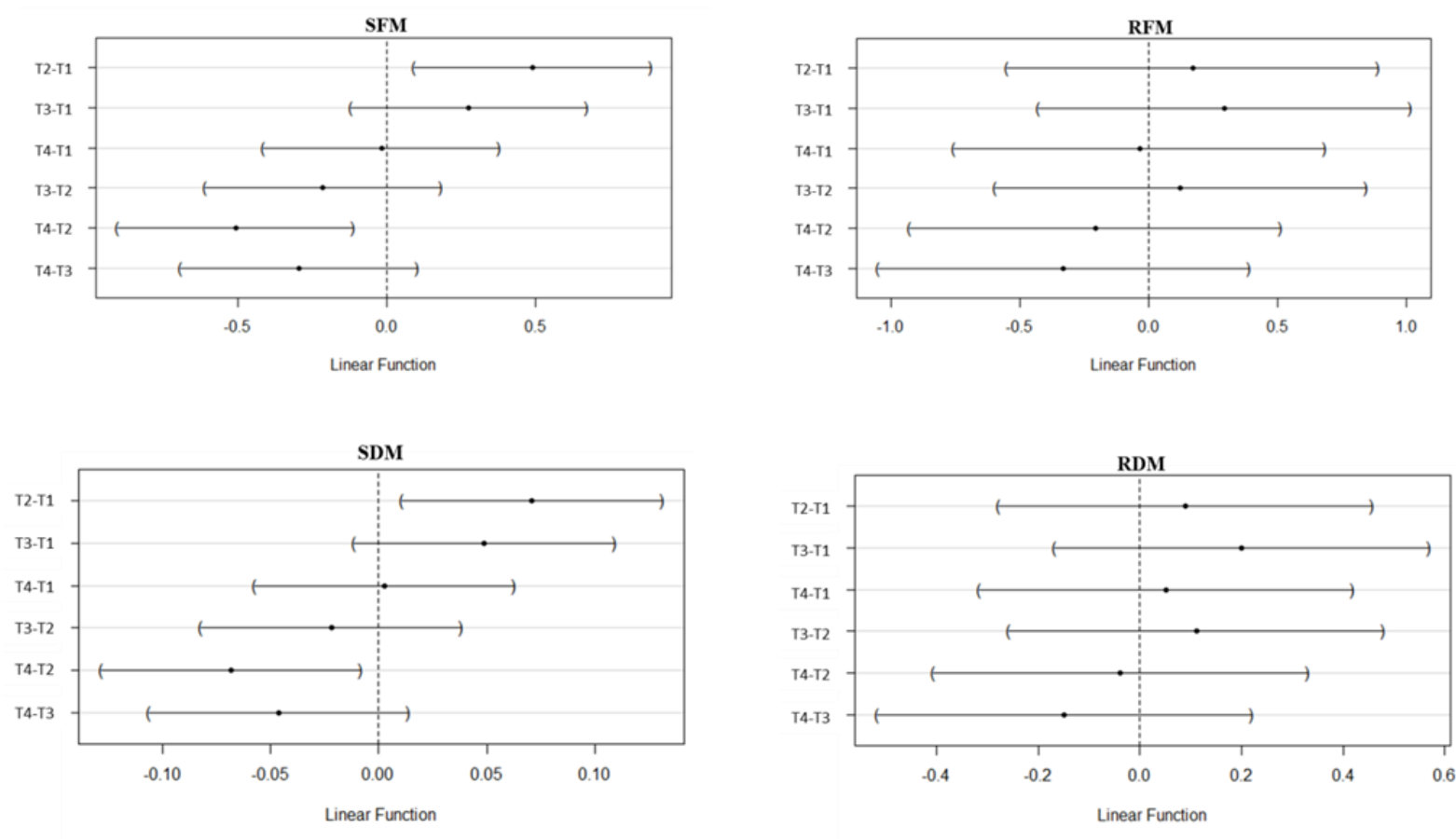

Figure 4. Statistical difference for shoot length (SL), shoot fresh mass (SFM), root fresh mass (RFM), shoot dry mass $(\mathrm{SDM})$ and root dry mass (RDM), between the in vitro conservation treatments of Neoregelia mucugensis. T1 - MS $1 / 2+$ 45 g. $\mathrm{L}^{-1}$ sucrose +7.8 g.L $\mathrm{L}^{-1}$ mannitol; T2 - MS 1/3 +45 g. $\mathrm{L}^{-1}$ sucrose +7.8 g. $\mathrm{L}^{-1}$ mannitol; T3 - MS $1 / 2+45$ g.L $\mathrm{L}^{-1}$ sucrose + 15.6 g. $\mathrm{L}^{-1}$ mannitol; T4 - MS $1 / 3+45$ g. $\mathrm{L}^{-1}$ sucrose +15.6 g.L $\mathrm{L}^{-1}$ mannitol, after 365 days of culture.

Table 2. Shoot length (SL), shoot fresh mass (SFM) and shoot dry mass (SDM) as a function of treatments with in vitro conservation of Neoregelia mucugensis after 365 days of culture.

\begin{tabular}{cccccc}
\hline Treatment & Salt concentration (MS) & Mannitol $\left(\mathrm{g} . \mathrm{L}^{-1}\right)$ & SL $(\mathrm{cm})$ & SFM $(\mathrm{g})$ & SDM $(\mathrm{g})$ \\
\hline $\mathrm{T} 1$ & $1 / 2$ & 7.8 & $5.01 \mathrm{~B}$ & $0.60 \mathrm{~B}$ & $0.12 \mathrm{~B}$ \\
$\mathrm{~T} 2$ & $1 / 3$ & 7.8 & $7.62 \mathrm{~A}$ & $1.06 \mathrm{~A}$ & $0.19 \mathrm{~A}$ \\
$\mathrm{~T} 3$ & $1 / 2$ & 15.6 & $5.44 \mathrm{~B}$ & $0.83 \mathrm{~A}$ & $0.16 \mathrm{~A}$ \\
$\mathrm{~T} 4$ & $1 / 3$ & 15.6 & $4.94 \mathrm{~B}$ & $0.58 \mathrm{~B}$ & $0.12 \mathrm{~B}$ \\
\hline
\end{tabular}

Means followed by the same uppercase letters in the columns do not differ from each other by Tukey test at $5 \%$ probability level. 


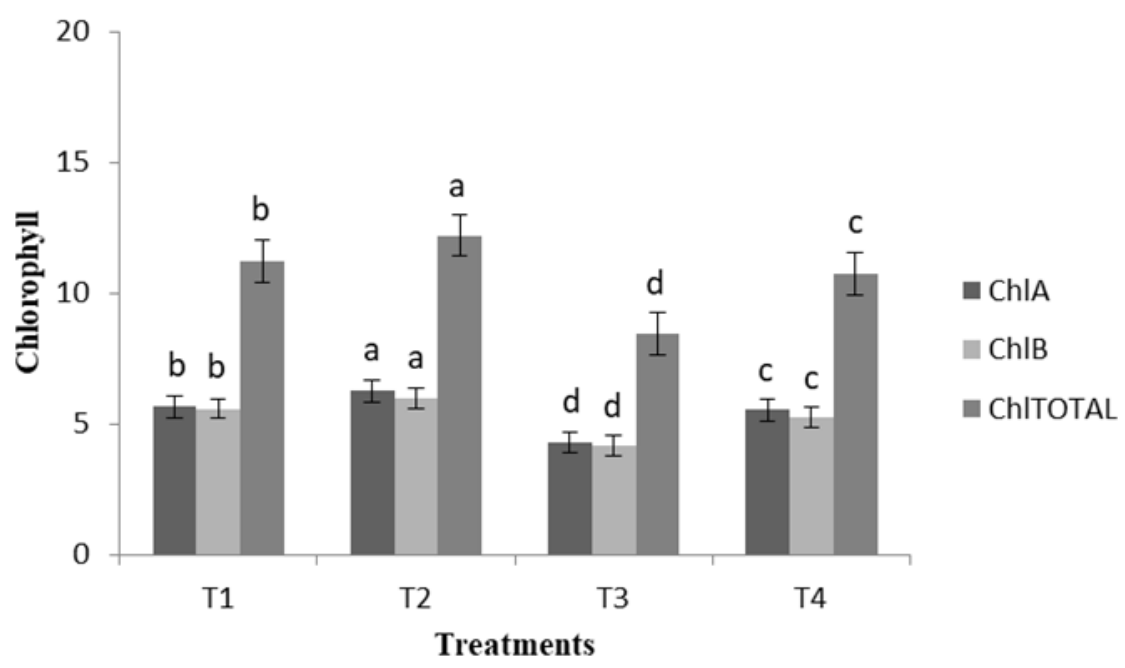

Figure 5. Chlorophyll content of Neoregelia mucugensis plants conserved in vitro for 365 days, as a function of treatment. T1 - MS 1/2 +45 g.L $L^{-1}$ sucrose +7.8 g.L. $\mathrm{L}^{-1}$ mannitol; T2 - MS 1/3 +45 g.L $\mathrm{L}^{-1}$ sucrose +7.8 g.L $\mathrm{L}^{-1}$ mannitol; T3 - MS $1 / 2+45$ g.L $\mathrm{L}^{-1}$ sucrose +15.6 g.L. $\mathrm{L}^{-1}$ mannitol; T4 - MS $1 / 3+45$ g. $\mathrm{L}^{-1}$ sucrose +15.6 g. $\mathrm{L}^{-1}$ mannitol. Letters indicate difference between treatments by Tukey test at $5 \%$ probability level, in each type of chlorophyll. Vertical lines in the top of the graph columns represent standard error.

Chlorophylls are considered the pigments of greatest abundance in plants, and structurally their molecules are composed of complexes derived from porphyrin and have magnesium $(\mathrm{Mg})$ as the central atom. Chlorophylls $a$ and $b$ are linked to the photosynthesis process and can be influenced by factors such as luminosity, water stress (STREIT et al., 2005), and mineral nutrition of plants. Considering that the reduction in the absorption of elements such as manganese can decrease chlorophyll levels, since it participates in the synthesis of these molecules (PEREIRA et al., 2016), the lowest means were expected to be obtained in treatments with more negative osmotic potentials, that is, T3 and T4, as observed.

Regarding the regenerative capacity of plant tissues conserved in vitro, there was significant influence $(p \leq 0.05)$ of the treatments used during the slow growth induction stage for both the percentage of responsive explants $(\% \mathrm{RE})$ and the number of shoots per explant (NS) (Figure 6).
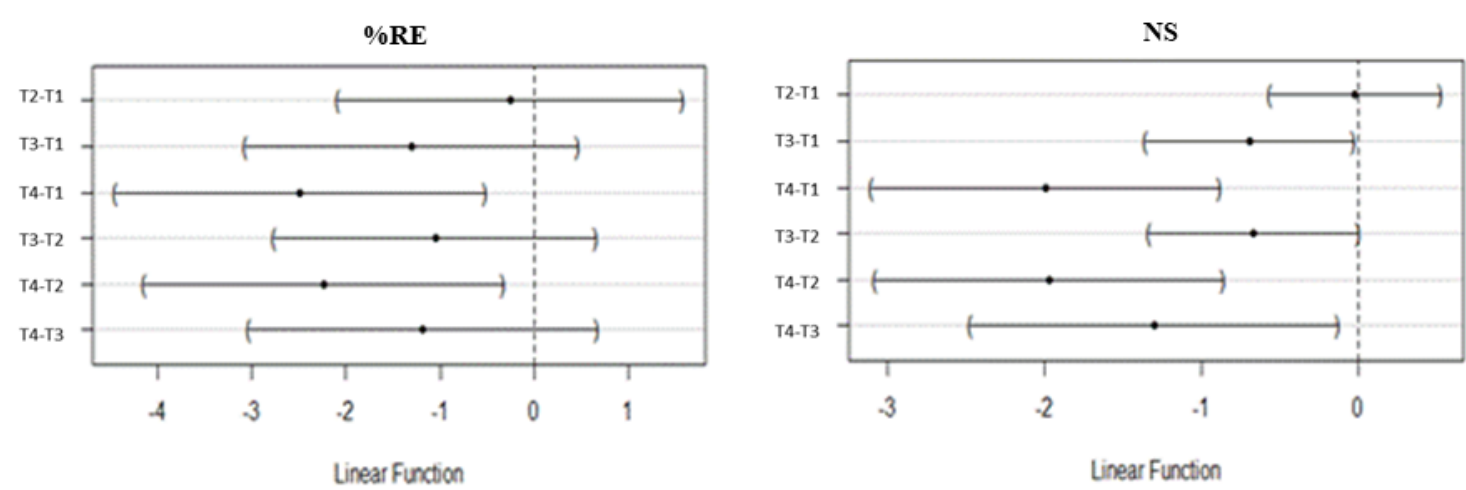

Figure 6. Statistical difference for percentage of responsive explants (\%RE) and number of shoots per explant (NS) of stem segments from Neoregelia mucugensis plants conserved in vitro for 365 days.

It was observed that the stem explants excised from the plants conserved in the treatments containing 7.8 g.L $\mathrm{L}^{-1}$ of mannitol (1 and 2) had 70 and $75 \%$ of responsive explants, differing statistically from treatment $4(20 \%)$, with $15.8 \mathrm{~g} . \mathrm{L}^{-1}$ of this carbohydrate (Figure 7). The same behavior was observed for the number of shoots, but treatments 1 and 2 (2.2 and 2.15) (Figure 8) were statistically superior to 3 and 4 (1.10 and 0.3) (Figure 7). 

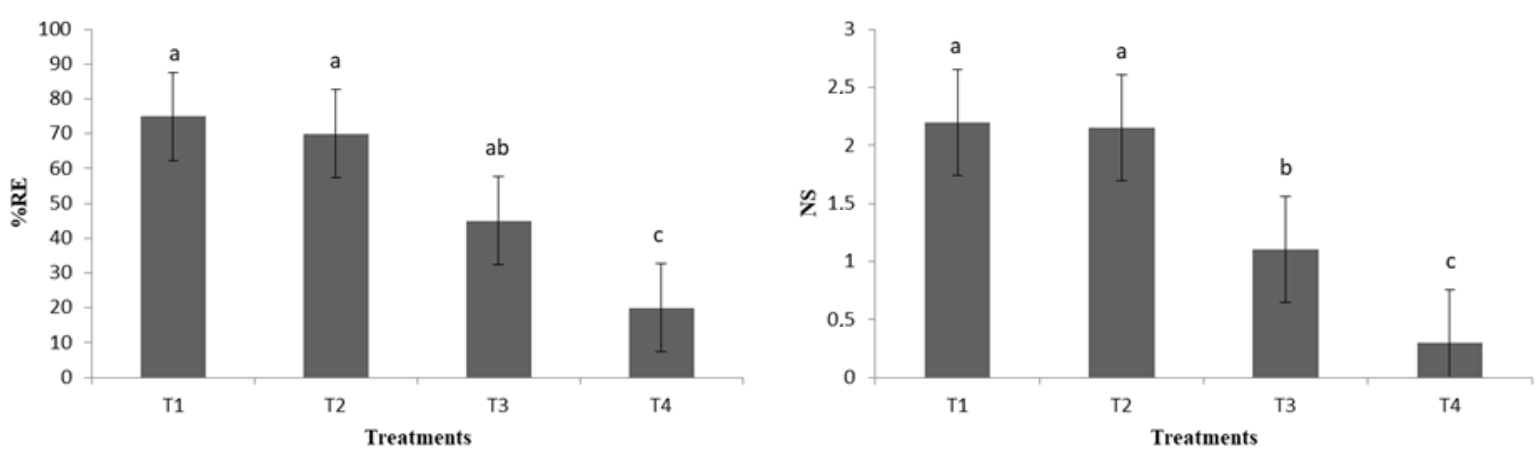

Figure 7. Means for regenerative capacity of stem segments from Neoregelia mucugensis plants conserved in vitro for 365 days in different culture media: T1 - MS 1/2 +45 g.L. ${ }^{-1}$ sucrose +7.8 g.L $\mathrm{L}^{-1}$ mannitol; T2 - MS $1 / 3+45$ g.L $\mathrm{L}^{-1}$ sucrose +7.8 g.L ${ }^{-1}$

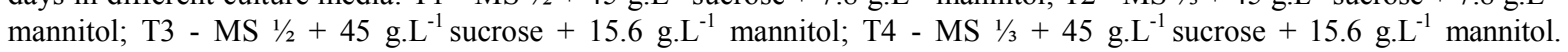
Percentage of responsive explants (\%RE) and number of shoots per explant (NS). Equal letters do not differ from each other by Tukey test at 5\% probability level. Vertical lines in the top of the graph columns represent standard error.

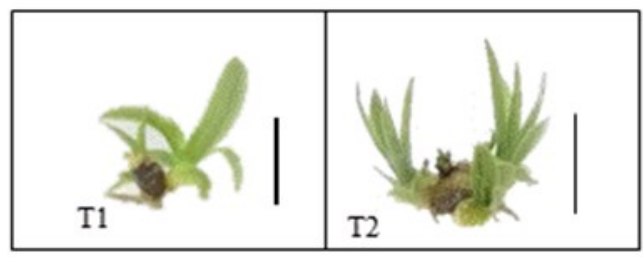

Figure 8. Sprouting in stem segments of Neoregelia mucugensis plants conserved in vitro for 365 days in culture medium: T1 - MS $1 / 2+45$ g. $\mathrm{L}^{-1}$ sucrose +7.8 g. $\mathrm{L}^{-1}$ mannitol and T2 - MS 1/3 +45 g. $\mathrm{L}^{-1}$ sucrose +7.8 g.L $\mathrm{L}^{-1}$ mannitol, and regenerated in medium containing BAP and ANA. Bar: $1 \mathrm{~cm}$.

These results show that, after the conservation period, the plants maintained the regenerative capacity of their tissues, verified by the formation of shoots in the stem explants. Therefore, the best responses were obtained for explants excised from plants conserved in medium containing 7.8 g. $\mathrm{L}^{-1}$ of mannitol and probably the lowest osmotic potential, allowing a greater absorption of nutrients. It is essential for an active germplasm bank that its plants maintain their regeneration potential, being available as genetic material for further studies, as well as for the production of micropropagated seedlings.

\section{CONCLUSION}

Tissue culture is an efficient alternative for the ex situ conservation of Neoregelia mucugensis. Plants conserved in vitro in MS $1 / 2$ medium with 7.8 g. $\mathrm{L}^{-1}$ of mannitol are induced to slow growth, showing high survival rates, and maintenance of regenerative capacity at the end of the one-year period.

\section{REFERÊNCIAS}

ARNON, D. I. Copper enzymes in isolated chloroplasts -polyphenoloxidase in Beta vulgaris. Plant Physiology, 24: 1-15, 1949.

BELLINTANI, M. C. et al. Estabelecimento in vitro de Orthophytum mucugense e Neoregelia mucugensis, bromélias endêmicas da Chapada Diamantina, Bahia - Brasil. Revista Brasileira de Biociências, 5: 1101-1103, 2007.

BELLINTANI, M. C. et al. Resposta regenerativa in vitro de explantes caulinares de bromélias endêmicas da Chapada Diamantina, Bahia. Magistra, 20: 328$337,2008$.

BELLO-BELLO, J. J.; GARCÍA-GARCÍA, G. G.; IGLESIAS-ANDREU, L. Conservación de vainilla (Vanilla planifolia Jacks.) bajo condiciones de lento crecimiento in vitro. Revista Fitotecnia Mexicana, 38: 165-171, 2015.

BETTENCOURT, G. M. F. et al. Efeito da fonte de carbono na embriogênese somática em Bactris gasipaes. Pesquisa Florestal Brasileira, 36: 179183,2016

CARVALHO, I. R. et al. Desempenho físiológico da soja com regulação hídrica por manitol. Agrarian, 9: 34-43, 2016. 
CNCFlora - Centro Nacional de Conservação da Flora.. Bromeliaceae in Lista Vermelha da flora brasileira versão. 2012. Disponível em: <http:// www.cncflora.jbrj.gov.br/portal/pt-br/listavermelha/ BROMELIACEAE>. Acesso em 18 fev. 2020.

FERREIRA, A. C. T. et al. Water and salt stresses on germination of cowpea (Vigna unguiculata cv. brs tumucumaque) seeds. Revista Caatinga, 30: 10091016, 2017.

FIGUEIREDO, M. L. et al. In vitro establishment and conservation of Aechmea bambusoides LB Smith \& Reitz, a threatened bromeliad species from Brazil. Revista Brasileira de Horticultura Ornamental, 14: 99-103, 2008.

FLORA DO BRASIL. Bromeliaceae in Flora do Brasil 2020 em construção. Jardim Botânico do Rio de Janeiro. Disponível em: http:// floradobrasil.jbrj.gov.br/reflora/floradobrasil/FB66. Acesso em: 28 Jan. 2020.

JENSEN, A. S. C. et al. Bromélia: promoção da biodiversidade $\mathrm{x}$ riscos à saúde ambiental. Revista Brasileira de Ciências Ambientais, 19: 38-45, 2011.

LIMA-BRITO, A. et al. Agentes osmóticos e temperatura na conservação in vitro de sempre-viva. Ciência Rural, 41 :1354-1361, 2011.

MURASHIGE, T.; SKOOG, F. A. Revised medium for rapid growth and bio assays with tobacco tissue cultures. Physiology Plant, 15: 473-497, 1962.

PALHA, P. M. G. et al. Parâmetros ecológicos de fungos em Bromeliaceae em ecossistemas naturais e cultivadas na Bahia. Rodriguésia, 69: 2025-2033, 2018.

PEREIRA, C. S. et al. Phytotoxicity in transgenic soybean treated with glyphosate doses. Scientific Electronic Archives, 9: 52-61, 2016.

R CORE TEAM (2018). R: A language and environment for statistical computing. $R$ Foundation for Statistical Computing, Vienna, Austria. URL https://www.R-project.org/.

RAPINI, A. et al. A flora dos campos rupestres da Cadeia do Espinhaço. Megadiversidade, 4: 16-23, 2008.

RODRIGUES, P. H. V.; ARRUDA, F.; FORTI, V. A. Slow-grown in vitro conservation of Heliconia champneiana cv. Splash under different light spectra. Scientia Agricola, 75: 163-166, 2018.
SÁ, A. J.; LÊDO, A. S.; LÊDO, C. A. S. Conservação in vitro de mangabeira da região nordeste do Brasil. Ciência Rural, 41: 57-62, 2011.

SASAMORI, M. H.; ENDRES-JUNIOR, D.; DROSTE, A. Conservation of Vriesea flammea L.B.Sm., an endemic Brazilian bromeliad: effects of nutrients and carbon source on plant development. Brazilian Journal of Biology, 80: 437-448, 2020.

SCHUTTZ, R.; ARAÚJO, L. C.; SÁ, F. S. Bromélias: abrigos terrestres de vida de água doce na floresta tropical. Natureza, 10:89-92, 2012.

SILVA, A. B. et al. Efeito da luz e do sistema de ventilação natural em abacaxizeiro (Bromeliacea) micropropagado. Bioscience Journal, 30: 380-386, 2014.

SILVA, N. D. G. et al. Conservação in vitro de amoreira-preta: Crescimento lento. Plant Cell Culture \& Micropropagation, 12: 7-12, 2016.

SILVEIRA, D. G. et al. Micropropagation and in vitro conservation of Neoglaziovia variegata (Arr. Cam.) Mez, a fiber producing bromeliad from Brazil. Brazilian Archives of Biology and Technology, 52: 923-932, 2009.

STREIT, N. M. et al. As clorofilas. Ciência Rural, 35: 748-755, 2005

TAIZ, L. et al. Fisiologia e desenvolvimento vegetal. 6. ed. Porto Alegre, RS: Artmed, 2017. 858 p. 